\title{
Physical attributes of ultisol of Brazil's northeastern semiarid under organic farming of wine grapes
}

\author{
JARDENIA R. FEITOSA ${ }^{1}$, ALESSANDRA M.S. MENDES ${ }^{2}$, NELCI OLSZEVSKI ${ }^{3}$, \\ TONY J.F. CUNHA ${ }^{2}$, JORGE W. CORTEZ ${ }^{4}$ and VANDERLISE GIONGO ${ }^{2}$ \\ ${ }^{1}$ Universidade Federal de Viçosa/UFV, Departamento de Engenharia Agrícola, \\ Av. P H Rolfs, s/n, Campus Universitário, 36570-000 Viçosa, MG, Brasil \\ ${ }^{2}$ Embrapa Semiárido, BR 428, Km 152, Zona Rural, Caixa Postal 23, 56302-970 Petrolina, PE, Brasil \\ ${ }^{3}$ Universidade Federal do Vale do São Francisco/UNIVASF, Colegiado de Engenharia Agrícola, \\ Avenida Antônio Carlos Magalhães, 510, Country Club, 48902-300 Juazeiro, BA, Brasil \\ ${ }^{4}$ Universidade Federal da Grande Dourados/UFGD, Faculdade de Ciências Agrárias/FCA, \\ Rodovia Dourados-Itanhum, Km 12, 79804-970 Dourados, MS, Brasil
}

Manuscript received on April 12, 2014; accepted for publication on April 7, 2014

\begin{abstract}
The purpose of this study was to evaluate the effects of organic farming of wine grapes under physical and chemical characteristics of Ultisol Brazil's northeastern semiarid region. The samples of soil were collected from the row and interrow of the farming and from the fallow area, at the depths of 0.0-0.10, 0.10$0.20,0.20-0.30$ and $0.30-0.60 \mathrm{~m}$. The samples were collected at six and twelve months after the culture implementation to evaluate the state of aggregation, bulk density and total soil porosity, flocculation index and organic matter contents, calcium, magnesium, and sodium. The results were submitted to statistical analysis. The adoption of organic farming contributed to the soil aggregation process. The bulk density and total soil porosity did not differ significantly between the evaluations, but were within the critical limits for sandy soils. The index flocculation did not have a great influence on the aggregates formation, being this process influenced by organic matter. The period of one year was considered short to obtain conclusive results in improving the soil quality by organic farming, since there are difficulties in tropical soils in promoting significant increases in organic matter content in short time.
\end{abstract}

Key words: aggregate stability, organic farming, soil quality, vitiviniculture.

\section{INTRODUCTION}

Amidst the agricultural activities carried out in Brazil, viticulture stands out due to its economic importance conquered in the recent decades. Such production can be found in many regions - mainly in the South, Southeast, and Northeast - in a development process

Correspondence to: Nelci Olszevski

E-mail: nelci.olszevski@univasf.edu.br under diverse edaphic and climatic factors. The São Francisco Valley in the Northeast - located in the tropical semiarid region of Brazil, latitude $9^{\circ} \mathrm{S}$, longitude $40^{\circ} \mathrm{W}$ and altitude of approximately $350 \mathrm{~m}$ - is the main vineyard tropical region of Brazil, with approximately 8,000 acres distributed between the states of Bahia and Pernambuco (Protas et al. 2008). According to Vital (2009), the production 
system of the wine of the São Francisco Valley is in its process of consolidation, finding barriers like the concentration of domestic wine market in the South and Southeast, low prices of imported products, and low advertising, which is improving but still subtle. As any other agricultural activity, it requires the use of good quality soil, with biological, chemical, and physical characteristics to assure good productivity. One alternative is the adoption of organic farming, whose principle is the continuous addition of organic matter to the soil and not the use of agrochemicals such as pesticides and industrial fertilizers. Important functions of organic matter include the formation of stable aggregates and soil surface protection, maintenance of vast array of biological functions, including the immobilization and release of nutrients, provision of ion exchange capacity, and storage of terrestrial C (Craswell and Lefroy 2001, Robert 2001). Even though the soil has an inherent quality with regards to its physical, chemical and biological properties, land management plays an important role on soil quality (Doran 2002). Thus, organic production systems are indicated to be used due to their low external inputs, and soil management practices are employed aiming to minimize deleterious effects on the environment. According to Oquist et al. (2007) alternative agricultural practices, such as soils cropped under organic systems have also been described as environmentally beneficial. Thus, producers of organic viticulture have an important argument about the health of the consumer, particularly with respect to lack of residual pesticides in wine (Bolonhez 2009). Furthermore, the organic production system provides increasing of soil organic matter content assisting in the improvement of soil quality, which according Lima et al. (2007) is the ability to perform functions interfering in the plants productivity and quality environmental. According to Larson and Pierce (1994) occurs by combining biological, chemical, and physical soil properties that provide the means for vegetable production, for the regulation water flow in the environment, and to work as an environmental filter in the attenuation and degradation of dangerous and harmful elements to the environment.

The purpose of this study was to evaluate the effects of organic farming of wine grapes under the characteristics of the Ultisol of Brazil's northeastern semiarid to understand the dynamic of the processes that occur in the soil as a consequence of the adoption of such system.

\section{MATERIALS AND METHODS}

This study was carried out in Winery Bianchetti Tedesco, located in Irrigation District Senator Nilo Coelho, in Petrolina $\left(09^{\circ} 23^{\prime} \mathrm{S}\right.$; $40^{\circ} 30^{\prime} \mathrm{W}$; at an altitude of $376 \mathrm{~m}$ above sea level), state of Pernambuco, Brazil. The study was conducted in an organic orchard of vine wine in sandy Ultisol (Table I) with drip irrigation. The climate of this region is classified as Bswh (Köeppen), which corresponds to a semiarid region with an average annual temperature of $26^{\circ} \mathrm{C}$ and average minimum and maximum temperatures of 21.2 and $32.7^{\circ} \mathrm{C}$, respectively. The average annual rainfall is 481.7 $\mathrm{mm}$, and the majority of the rainfall is observed during the months of February to April. The dry season occurs from June to November, and the average relative humidity is $67 \%$.

TABLE I

Granulometric composition of the Ultisol at different soil sample depths after plowing

\begin{tabular}{cccc}
\hline Depth & Clay & Sand & Silt \\
\hline$m$ & & $\mathrm{~kg} \cdot \mathrm{kg}^{-1}$ & \\
\hline $0.00-0.10$ & 0.064 & 0.893 & 0.043 \\
$0.10-0.20$ & 0.080 & 0.888 & 0.032 \\
$0.20-0.30$ & 0.093 & 0.875 & 0.032 \\
$0.30-0.60$ & 0.112 & 0.856 & 0.032 \\
\hline
\end{tabular}

The fertilization of the orchard was performed with a compound of castor bean pie, potassium, and manure applied at $60 \mathrm{~cm}$ deep. The planting of the seedlings occurred in April 2010. The orchard received weekly $10 \mathrm{~g} /$ plant of organic compound 
whose composition was: $50 \mathrm{~kg}$ of castor bean pie $(5 \% \mathrm{~N}, 35 \% \mathrm{C}), 10 \mathrm{~kg}$ of $\mathrm{K}$ (potassium sulfate and magnesium $\left.=21 \% \mathrm{~K}_{2} \mathrm{O}+10 \% \mathrm{Mg}+21 \% \mathrm{~S}\right), 10 \mathrm{~kg}$ of $\mathrm{P}\left(\right.$ Gafsa rock phosphate $=28 \% \mathrm{P}_{2} \mathrm{O}_{5}$ total $), 10 \mathrm{~kg}$ of $\mathrm{Mg}$ (magnesium oxide $=52 \% \mathrm{Mg}$ ), and $20 \mathrm{~mL}$ vector 1000 (brand Lieknin). The chemical characteristics of the organic compound are presented in the Table II. In the interrow of the plantation, initially a cocktail consisting of pigeon pea seeds (Cajanus cajan), jack-bean (Canavalia ensiformis), mucuna (Mucuna spp.), sunflower (Helianthus annuus), crotalaria (Crotalaria spp.), millet (Pennisetum glaucum), and sorghum (Sorghum bicolor) was seeded. Fifty days after planting the cover plants were cut near the base and left on the surface of the ground. The area is maintained with spontaneous vegetation and covers plants for green manure or for the deposition of organic material produced ex-situ.

TABLE II

Chemical analysis of the organic

compound applied to the orchard.

\begin{tabular}{|c|c|c|c|c|c|c|c|c|c|c|}
\hline $\mathbf{N}$ & $\mathbf{P}$ & K & $\mathbf{M g}$ & $\mathbf{S}$ & B & $\mathbf{C u}$ & $\mathrm{Fe}$ & Mn & $\mathrm{Zn}$ & $\mathrm{Na}$ \\
\hline & & $g \cdot k g$ & & & & & & $\cdot \mathrm{kg}^{-1}$ & & \\
\hline 37.99 & 20.18 & 26.69 & 53.00 & 58.00 & 48.04 & 20.67 & 2210.00 & 112.00 & 98.00 & 2111.57 \\
\hline
\end{tabular}

Soil samples were collected in two periods: at six and twelve months after culture implementation, from the $0-0.10 \mathrm{~m}, 0.10-0.20 \mathrm{~m}, 0.20-0.30 \mathrm{~m}$ and $0.30-0.60 \mathrm{~m}$ layers. A completely randomized block design was used with treatments constituted by sampling sites (rows, interrows and in the fallow), with three replications for treatment.

Undisturbed soil samples were used to evaluate aggregates stability (Kiehl 1979) and to calculate geometric mean diameter (GMD) (Melo et al. 2008) and mean weight diameter (MWD) (Kiehl 1979, Castro Filho et al. 1998). Disturbed soil samples were used to determine soil texture and water-dispersible clay (Ruiz 2004) and to calculate flocculation index (FI). Soil bulk density (BD) and soil particles density (PD) were determined by Embrapa methods (Embrapa 1997) and the total soil porosity (TP) was calculated from $\mathrm{BD}$ and $\mathrm{PD}$. The soil organic carbon and $\mathrm{Ca}^{2+}, \mathrm{Mg}^{2+}$, and $\mathrm{Na}^{+}$were determined by methods described by (Embrapa 1997).

The data obtained, for each sampling period, were submitted to variance analysis and Tukey's test at $5 \%$ probability level $(\mathrm{p}<0.05)$ using the software Assistat 7.6 (Silva and Azevedo 2002). The sampling periods were compared by paired t-test at $5 \%$ probability level $(\mathrm{p}<0.05)$ using the software Statistica 7.0 (Calado and Montgomery 2003).

\section{RESULTS}

\section{SOIL AGGREGATION}

The soil structure stability concerns the aggregates resistance to the water disaggregation force and mechanical operations and can be evaluated through indices such as MWD and GMD. Six months after orchard implementation, higher values of MWD were found in the fallow area (Table III).

Twelve months after culture implementation, the largest diameter on the superficial layer was also found in the fallow area, whereas the values for the row and interrow did not differ significantly (Table III).

The sampling sites had different behaviors regarding the values of MWD at different depths, no significant differences occurred among them and the samples collected in the planting interrow. In the row, the highest values were found at 0.20 $0.30 \mathrm{~m}$ and $0.30-0.60 \mathrm{~m}$ depth, whereas in the fallow area the highest value was obtained at 0.00-0.10m depth. 
TABLE III

Mean of the mean weight diameter (MWD) of the soil collected at different sites and depth six and twelve months after orchard implementation.

\begin{tabular}{ccccc}
\hline \multicolumn{5}{c}{ 6 months } \\
\hline \multirow{2}{*}{ Sites } & \multicolumn{5}{c}{ Soil sample depth (m) } \\
\cline { 2 - 5 } & $\mathbf{0 . 0 0 - 0 . 1 0}$ & $\mathbf{0 . 1 0 - 0 . 2 0}$ & $\mathbf{0 . 2 0 - 0 . 3 0}$ & $\mathbf{0 . 3 0 - 0 . 6 0}$ \\
\hline Row & $0.597 \mathrm{bA}$ & $0.444 \mathrm{bB}$ & $0.514 \mathrm{bAB}$ & $0.503 \mathrm{bAB}$ \\
Interrow & $0.478 \mathrm{bA}$ & $0.562 \mathrm{bA}$ & $0.472 \mathrm{bA}$ & $0.549 \mathrm{bA}$ \\
Fallow area & $0.819 \mathrm{aAB}$ & $0.724 \mathrm{aB}$ & $0.876 \mathrm{aA}$ & $0.854 \mathrm{aAB}$ \\
\hline \multirow{2}{*}{ Sites } & \multicolumn{5}{c}{$\mathbf{1 2}$ months } \\
\cline { 2 - 5 } & $\mathbf{0 . 0 0 - 0 . 1 0}$ & $\mathbf{0 . 1 0 - 0 . 2 0}$ & $\mathbf{0 . 2 0 - 0 . 3 0}$ & $\mathbf{0 . 3 0 - 0 . 6 0}$ \\
\hline Row & $0.698 \mathrm{bB}$ & $0.800 \mathrm{aB}$ & $1.177 \mathrm{aA}$ & $0.968 \mathrm{aAB}$ \\
Interrow & $0.823 \mathrm{bA}$ & $0.808 \mathrm{aA}$ & $0.849 \mathrm{bA}$ & $0.735 \mathrm{aA}$ \\
Fallow area & $1.110 \mathrm{aA}$ & $0.714 \mathrm{aB}$ & $0.805 \mathrm{bAB}$ & $0.727 \mathrm{aB}$ \\
\hline
\end{tabular}

Means followed by similar lowercase letters in the column and uppercase letters in the line are not significantly different at $\mathrm{p} \leq 0.05$ by Tukey's test.

The GMD, which is pointed as the index that better gets close to the mean diameter of aggregates (Lier and Albuquerque 1997), at six months showed the highest values for fallow area, although among depths of 0.10-0.60 m they did not differ significantly among the sampling sites (Table IV). GMD did not differ significantly when only the soil sample depth was considered, and there was no significant interaction between sampling sites and depths. The GMD at 12 months behaved similarly between sampling sites and depths (Table IV), with no significant interaction between sampling sites and depths.

However, both MWD (Table V) and GMD (Table VI) averages at 12 months were higher
TABLE IV

Mean of geometric mean diameter (GMD) of the soil collected at different sites and depth at the six and twelve months after orchard implementation.

\begin{tabular}{ccc}
\hline \multicolumn{3}{c}{ GMD $(\mathbf{m m})$} \\
\cline { 2 - 3 } 6 Months & 12 Months \\
\hline \multicolumn{3}{c}{ Sites } \\
\hline Row & $0.370 \mathrm{ab}$ & $0.488 \mathrm{a}$ \\
Interrow & $0.345 \mathrm{~b}$ & $0.513 \mathrm{a}$ \\
Fallow área & $0.472 \mathrm{a}$ & $0.460 \mathrm{a}$ \\
\hline \multicolumn{3}{c}{ Soil sample depths (m) } \\
\hline $0.00-0.10$ & $0.424 \mathrm{a}$ & $0.496 \mathrm{a}$ \\
$0.10-0.20$ & $0.367 \mathrm{a}$ & $0.524 \mathrm{a}$ \\
$0.20-0.30$ & $0.406 \mathrm{a}$ & $0.486 \mathrm{a}$ \\
$0.30-0.60$ & $0.385 \mathrm{a}$ & $0.442 \mathrm{a}$ \\
\hline \multicolumn{3}{c}{ Factors } \\
\hline Site & $5.437^{*}$ & $0.999^{\text {ns }}$ \\
Depth & $0.556^{\text {ns }}$ & $1.213^{\text {ns }}$ \\
S X D & $0.863^{\text {ns }}$ & $1.033^{\text {ns }}$ \\
Blocks & $0.032^{\text {ns }}$ & $0.825^{\text {ns }}$ \\
CV (\%) & 25.2 & 19.0 \\
\hline
\end{tabular}

Means followed by similar letters are not significantly different at $\mathrm{p} \leq 0.05$ by Tukey's test. *: significant at $\mathrm{p} \leq$ 0.05 by Test $F$; ${ }^{\text {ns: }}$ non-significant.

than those obtained at 6 months after the culture implementation. Comparing the GMD averages between the two periods, for each sampling site and depth, through the paired t-test, it was observed that there was no significant difference at 5\% probability in most of the sampling sites. However, the diameters found at twelve months were higher than those obtained at six months, for all soil sample depths in the row and interrow.

TABLE V

Paired t-test for comparison of the mean weight diameter (MWD) between the two periods of collection

\begin{tabular}{|c|c|c|c|c|c|c|c|c|c|}
\hline \multicolumn{10}{|c|}{ MWD } \\
\hline Depth & \multicolumn{2}{|c|}{ Row } & & \multicolumn{2}{|c|}{ Interrow } & \multicolumn{4}{|c|}{ Fallow } \\
\hline & 6 months & 12 months & & 6 months & 12 months & & 6 months & 12 months & \\
\hline $\mathrm{m}$ & \multicolumn{2}{|c|}{$\mathrm{mm}$} & & \multicolumn{2}{|c|}{$\mathrm{mm}$} & \multicolumn{4}{|c|}{$\mathrm{mm}$} \\
\hline $0.00-0.10$ & 0.597 & 0.698 & ns & 0.478 & 0.823 & ns & 0.881 & 1.110 & ns \\
\hline $0.10-0.20$ & 0.444 & 0.800 & $*$ & 0.562 & 0.808 & ns & 0.724 & 0.714 & ns \\
\hline $0.20-0.30$ & 0.514 & 1.177 & ns & 0.472 & 0.849 & $*$ & 0.876 & 0.805 & ns \\
\hline $0.30-0.60$ & 0.503 & 0.968 & $*$ & 0.549 & 0.735 & ns & 0.854 & 0.727 & ns \\
\hline
\end{tabular}

*: significant at $\mathrm{p} \leq 0.05$ by paired t-test; $n s$ : non-significant. 
TABLE VI

Paired t-test for comparison of the geometric mean diameter (GMD) between the two periods of collection

\begin{tabular}{|c|c|c|c|c|c|c|c|c|c|}
\hline \multicolumn{10}{|c|}{ GMD } \\
\hline Depth & \multicolumn{2}{|c|}{ Row } & & \multicolumn{2}{|c|}{ Interrow } & \multicolumn{4}{|c|}{ Fallow } \\
\hline & 6 months & 12 months & & 6 months & 12 months & & 6 months & 12 months & \\
\hline $\mathrm{m}$ & \multicolumn{2}{|c|}{$\mathrm{mm}$} & & \multicolumn{2}{|c|}{$\mathrm{mm}$} & \multicolumn{4}{|c|}{$\mathrm{mm}$} \\
\hline $0.00-0.10$ & 0.452 & 0.453 & ns & 0.303 & 0.485 & ns & 0.517 & 0.549 & $\mathrm{~ns}$ \\
\hline $0.10-0.20$ & 0.347 & 0.580 & ns & 0.340 & 0.549 & ns & 0.414 & 0.442 & ns \\
\hline $0.20-0.30$ & 0.334 & 0.474 & ns & 0.357 & 0.546 & $*$ & 0.528 & 0.437 & $\mathrm{~ns}$ \\
\hline $0.30-0.60$ & 0.349 & 0.444 & ns & 0.380 & 0.472 & ns & 0.427 & 0.410 & $\mathrm{~ns}$ \\
\hline
\end{tabular}

*: significant at $\mathrm{p} \leq 0.05$ by paired t-test; ns: non-significant.

No significant correlation between the organic matter content $(\mathrm{OM})$ and $\mathrm{Na}$ with soil aggregation index in the periods evaluated, were found (Table VII). Besides that, there was a positive correlation between $\mathrm{Ca}$ and $\mathrm{Mg}$ (Table VII).

TABLE VII

Correlation between chemical characteristics of soil and aggregation index.

\begin{tabular}{ccccc}
\hline \multirow{2}{*}{$\begin{array}{c}\text { Aggregation } \\
\text { Index }\end{array}$} & \multicolumn{4}{c}{ Chemical characteristics } \\
\cline { 2 - 5 } $\mathrm{Ca}^{2+}$ & $\mathrm{Mg}^{2+}$ & $\mathrm{Na}^{+}$ & $\mathrm{OM}$ \\
\hline GMD & $0.27^{*}$ & $0.29^{*}$ & $0.09 \mathrm{~ns}$ & $0.06 \mathrm{~ns}$ \\
MWD & $0.43^{*}$ & $0.36^{*}$ & $0.09 \mathrm{~ns}$ & $0.17 \mathrm{~ns}$ \\
\hline
\end{tabular}

*: significant at $\mathrm{p} \leq 0.05$ by t-test; ns: non-significant.
Regarding distribution of aggregates by diameter classes it is observed that for planting row and interrow occurred higher concentration of aggregates in the classes $0.500-0.250 \mathrm{~mm}$ and $0.250-0.125 \mathrm{~mm}$ and, statistically there were few differences between the sampling sites at each depth (Table VIII).

At 12 months (Table IX), the occurrence of more regular distribution of aggregates weight between the sampling sites for the same class it was observed, especially on the layers with $0.00-0.10$ $\mathrm{m}$ and $0.10-0.20 \mathrm{~m}$, in which the highest values of weight were found for the class with $0.500-0.250$ $\mathrm{mm}$, occurring even an increase when compared to the data of the first assessment.

TABLE VIII

Size distribution of aggregates at the six months after orchard implementation.

\begin{tabular}{|c|c|c|c|c|c|c|c|}
\hline \multicolumn{8}{|c|}{ Weight of aggregates (g) - 6 Months } \\
\hline \multirow{2}{*}{ Depths (m) } & \multicolumn{7}{|c|}{ diameter classes $(\mathrm{mm})$} \\
\hline & & $>2.00$ & $2.00-1.00$ & $1.00-0.500$ & $0.500-0.250$ & $0.250-0.125$ & $<0.125$ \\
\hline \multirow{3}{*}{$0.00-0.10$} & Row & $1.733 \mathrm{~b}$ & $3.478 \mathrm{a}$ & $4.268 \mathrm{a}$ & $6.460 \mathrm{a}$ & $5.198 \mathrm{a}$ & $2.076 \mathrm{a}$ \\
\hline & Interrow & $0.633 \mathrm{~b}$ & $1.680 \mathrm{a}$ & $3.185 \mathrm{a}$ & $7.012 \mathrm{a}$ & $7.135 \mathrm{a}$ & $3.358 \mathrm{a}$ \\
\hline & Fallow & $4.467 \mathrm{a}$ & $3.356 \mathrm{a}$ & $2.077 \mathrm{a}$ & $4.175 \mathrm{a}$ & $5.035 \mathrm{a}$ & $3.158 \mathrm{a}$ \\
\hline \multirow{3}{*}{$0.10-0.20$} & Row & $1.067 \mathrm{a}$ & $2.079 \mathrm{~b}$ & $2.958 \mathrm{a}$ & $7.919 \mathrm{a}$ & $6.350 \mathrm{a}$ & $2.931 \mathrm{a}$ \\
\hline & Interrow & $1.000 \mathrm{a}$ & $2.237 \mathrm{~b}$ & $3.820 \mathrm{a}$ & $6.402 \mathrm{a}$ & $6.639 \mathrm{a}$ & $3.160 \mathrm{a}$ \\
\hline & Fallow & $1.633 \mathrm{a}$ & $7.978 \mathrm{a}$ & $2.563 \mathrm{a}$ & $4.684 \mathrm{a}$ & $3.748 \mathrm{a}$ & $2.919 \mathrm{a}$ \\
\hline \multirow{3}{*}{$0.20-0.30$} & Row & $0.767 \mathrm{a}$ & $1.993 \mathrm{a}$ & $2.792 \mathrm{a}$ & $10.68 \mathrm{a}$ & $4.547 \mathrm{a}$ & $3.285 \mathrm{a}$ \\
\hline & Interrow & $0.700 \mathrm{a}$ & $2.472 \mathrm{a}$ & $4.068 \mathrm{a}$ & $8.072 \mathrm{a}$ & $4.897 \mathrm{a}$ & $3.382 \mathrm{a}$ \\
\hline & Fallow & $3.067 \mathrm{a}$ & $4.962 \mathrm{a}$ & $3.125 \mathrm{a}$ & $5.589 \mathrm{a}$ & $3.356 \mathrm{a}$ & $2.974 \mathrm{a}$ \\
\hline \multirow{3}{*}{$0.30-0.60$} & Row & $0.467 \mathrm{a}$ & $1.609 \mathrm{a}$ & $4.229 \mathrm{a}$ & $9.506 \mathrm{a}$ & $4.107 \mathrm{a}$ & $2.935 \mathrm{a}$ \\
\hline & Interrow & $0.333 \mathrm{a}$ & $2.171 \mathrm{a}$ & $6.014 \mathrm{a}$ & $7.931 \mathrm{a}$ & $3.680 \mathrm{a}$ & $2.888 \mathrm{a}$ \\
\hline & Fallow & $2.233 \mathrm{a}$ & $3.313 \mathrm{a}$ & $3.837 \mathrm{a}$ & $6.116 \mathrm{a}$ & $4.578 \mathrm{a}$ & $3.405 \mathrm{a}$ \\
\hline
\end{tabular}

Means followed by similar letters are not significantly different at $\mathrm{p} \leq 0.05$ by Tukey's test. 
TABLE IX

Size distribution of aggregates at the twelve months after orchard implementation.

\begin{tabular}{cccccccc}
\hline \multirow{7}{*}{ Depths (m) } & & \multicolumn{7}{c}{ diameter classes (mm) } \\
\cline { 3 - 8 } & & $>2.00$ & $2.00-1.00$ & $1.00-0.500$ & $0.500-0.250$ & $0.250-0.125$ & $<0.125$ \\
\cline { 3 - 8 } $0.00-0.10$ & Row & $1.164 \mathrm{a}$ & $3.712 \mathrm{a}$ & $4.438 \mathrm{a}$ & $8.024 \mathrm{a}$ & $3.883 \mathrm{a}$ & $2.058 \mathrm{a}$ \\
& Interrow & $2.420 \mathrm{a}$ & $3.908 \mathrm{a}$ & $3.312 \mathrm{a}$ & $7.412 \mathrm{a}$ & $3.967 \mathrm{a}$ & $2.463 \mathrm{a}$ \\
& Fallow & $4.077 \mathrm{a}$ & $4.597 \mathrm{a}$ & $2.662 \mathrm{a}$ & $6.095 \mathrm{a}$ & $3.712 \mathrm{a}$ & $2.937 \mathrm{a}$ \\
\hline \multirow{2}{*}{$0.10-0.20$} & Row & $2.963 \mathrm{a}$ & $4.348 \mathrm{a}$ & $3.737 \mathrm{a}$ & $7.221 \mathrm{a}$ & $2.909 \mathrm{a}$ & $1.808 \mathrm{a}$ \\
& Interrow & $2.799 \mathrm{a}$ & $4.882 \mathrm{a}$ & $3.509 \mathrm{a}$ & $7.425 \mathrm{a}$ & $2.882 \mathrm{a}$ & $2.443 \mathrm{a}$ \\
& Fallow & $2.911 \mathrm{a}$ & $2.999 \mathrm{a}$ & $3.319 \mathrm{a}$ & $6.371 \mathrm{a}$ & $4.191 \mathrm{a}$ & $3.266 \mathrm{a}$ \\
\hline \multirow{2}{*}{$0.20-0.30$} & Row & $3.824 \mathrm{a}$ & $3.953 \mathrm{a}$ & $3.197 \mathrm{a}$ & $6.353 \mathrm{a}$ & $3.443 \mathrm{a}$ & $2.580 \mathrm{a}$ \\
& Interrow & $1.744 \mathrm{a}$ & $5.039 \mathrm{a}$ & $6.082 \mathrm{a}$ & $6.026 \mathrm{a}$ & $2.591 \mathrm{a}$ & $2.335 \mathrm{a}$ \\
& Fallow & $2.505 \mathrm{a}$ & $3.021 \mathrm{a}$ & $3.137 \mathrm{a}$ & $7.418 \mathrm{a}$ & $3.953 \mathrm{a}$ & $2.964 \mathrm{a}$ \\
\hline \multirow{2}{*}{$0.30-0.60$} & Row & $1.917 \mathrm{a}$ & $3.653 \mathrm{a}$ & $4.696 \mathrm{ab}$ & $8.213 \mathrm{a}$ & $2.870 \mathrm{a}$ & $1.475 \mathrm{a}$ \\
& Interrow & $1.571 \mathrm{a}$ & $3.045 \mathrm{a}$ & $7.215 \mathrm{a}$ & $6.365 \mathrm{a}$ & $3.445 \mathrm{a}$ & $2.661 \mathrm{a}$ \\
& Fallow & $3.003 \mathrm{a}$ & $2.242 \mathrm{a}$ & $2.646 \mathrm{~b}$ & $6.030 \mathrm{a}$ & $2.818 \mathrm{a}$ & $2.530 \mathrm{a}$ \\
\hline
\end{tabular}

Means followed by similar letters are not significantly different at $\mathrm{p} \leq 0.05$ by Tukey's test.

\section{FLOCCULATION INDEX (FI)}

The FI of the soil represents the proportion of naturally flocculated clay compared to the total clay, allowing answers about the process of soil structure. Six months after the orchard implementation, the soil samples in the interrow presented lower IF (Table X). After twelve months of culture implementation, the cultivated area presented superior FI compared with the fallow area, with no significant difference among the soil sample depths and interaction between depths and the sampling sites (Table X).

Six months after the culture implementation, no significant differences were found regarding FI layers with $0.00-0.10$ and with $0.30-0.60 \mathrm{~m}$. However, for depths of 0.10-0.20 and 0.20-0.30 m, this index was the same for the row and fallow area and significantly higher than the interrow (Table XI).

Comparing the averages of the FI obtained in both periods, it was not possible to observe significant differences for the planting row and, among $0.10-0.60$ in the fallow area (Table XII).
TABLE X

Mean of the flocculation index (FI) of the soil collected in different sites and depth six and twelve months after orchard implementation.

\begin{tabular}{ccc}
\hline & FI & \\
\cline { 2 - 3 } & 6 Months & 12 Months \\
\hline Sites & $0,971 \mathrm{a}$ & $0,968 \mathrm{a}$ \\
Row & $0,957 \mathrm{~b}$ & $0,956 \mathrm{a}$ \\
Interrow & $0,973 \mathrm{a}$ & $0,941 \mathrm{~b}$ \\
\hline Fallow area & & \\
\hline Soil sample depths (m) & $0,975 \mathrm{a}$ & $0,954 \mathrm{a}$ \\
\hline $0.00-0.10$ & $0,972 \mathrm{a}$ & $0,960 \mathrm{a}$ \\
$0.10-0.20$ & $0,965 \mathrm{ab}$ & $0,951 \mathrm{a}$ \\
$0.20-0.30$ & $0,956 \mathrm{~b}$ & $0,955 \mathrm{a}$ \\
$0.30-0.60$ & & \\
\hline Factors & $10,361^{*}$ & $14,491^{*}$ \\
\hline Site & $7,232^{*}$ & $0,823^{\text {ns }}$ \\
Depth & $3,425^{*}$ & $1,578^{\text {ns }}$ \\
S X D & $0,992^{\text {ns }}$ & $0,470^{\text {ns }}$ \\
Blocks & 0,96 & 1,3 \\
CV $(\%)$ & &
\end{tabular}

Means followed by similar letter in the column are not significantly different at $\mathrm{p} \leq 0.05$ by Tukey's test.

*: significant at $\mathrm{p} \leq 0.05$ by Test $\mathrm{F}$; ${ }^{\text {ns }}$ : non-significant. 
TABLE XI

Mean of the flocculation index (FI) of the soil collected at different sites and depth six months after orchard implementation.

\begin{tabular}{ccccc}
\hline \multirow{2}{*}{ Sites } & \multicolumn{4}{c}{ Depths (m) } \\
\cline { 2 - 5 } & $0.00-0.10$ & $0.10-0.20$ & $0.20-0.30$ & $0.30-0.60$ \\
\hline Row & $0.972 \mathrm{aA}$ & $0.985 \mathrm{aA}$ & $0.977 \mathrm{aA}$ & $0.948 \mathrm{aB}$ \\
Interrow & $0.969 \mathrm{aA}$ & $0.955 \mathrm{bA}$ & $0.948 \mathrm{bA}$ & $0.958 \mathrm{aA}$ \\
Fallow area & $0.983 \mathrm{aA}$ & $0.977 \mathrm{aA}$ & $0.970 \mathrm{aA}$ & $0.963 \mathrm{aA}$ \\
\hline
\end{tabular}

Means followed by similar lowercase letters in the column and uppercase letters in the line are not significantly different at $\mathrm{p} \leq 0.05$ by Tukey's test.
Bulk Density of THE SoIL (BD) AND Total SoIL

POROSITY (TP)

Evaluating BD six months after orchard implementation, significant differences were observed among sampling sites (row, interrow and fallow area) at $0.0-0.10 \mathrm{~m}$ and $0.30-0.60 \mathrm{~m}$ depth, however, in the first it was smaller for the row. There was no difference between the fallow and interrow (Table XIII). At $0.30-0.60 \mathrm{~m}$ depth, the BD means in row and interrow became equal, although the fallow area had presented inferior values.

TABLE XII

Paired t-test for comparison of the flocculation index (FI) between the two periods of collection.

\begin{tabular}{|c|c|c|c|c|c|c|c|c|c|}
\hline \multicolumn{10}{|c|}{ FI } \\
\hline Depth & \multicolumn{2}{|c|}{ Row } & & \multicolumn{2}{|c|}{ Interrow } & \multicolumn{4}{|c|}{ Fallow } \\
\hline & 6 months & 12 months & & 6 months & 12 months & & 6 months & 12 months & \\
\hline$-m-$ & \multicolumn{2}{|c|}{$\mathrm{mm}$} & & \multicolumn{2}{|c|}{$-m m$} & \multicolumn{4}{|c|}{$\longrightarrow \mathrm{mm}$} \\
\hline $0.00-0,10$ & 0.972 & 0.970 & ns & 0.969 & 0.954 & $*$ & 0.983 & 0.939 & $*$ \\
\hline $0.10-0,20$ & 0.985 & 0.980 & ns & 0.955 & 0.952 & ns & 0.977 & 0.947 & ns \\
\hline $0.20-0,30$ & 0.977 & 0.968 & ns & 0.948 & 0.954 & ns & 0.970 & 0.931 & ns \\
\hline $0.30-0,60$ & 0.948 & 0.954 & ns & 0.958 & 0.964 & ns & 0.963 & 0.947 & ns \\
\hline
\end{tabular}

*: significant at $\mathrm{p} \leq 0.05$ by paired t-test; ns: non-significant.

TABLE XIII

Mean of soil Bulk density (BD) in soil samples collected at different sites and depth twelve months after orchard implementation.

\begin{tabular}{ccccc}
\hline \multirow{2}{*}{ Sites } & \multicolumn{4}{c}{ Depths (m) } \\
\cline { 2 - 5 } & $0.00-0.10$ & $0.10-0.20$ & $0.20-0.30$ & $0.30-0.60$ \\
\hline Row & $1.477 \mathrm{Ba}$ & $1.512 \mathrm{aA}$ & $1.547 \mathrm{aA}$ & $1.479 \mathrm{bA}$ \\
Interrow & $1.607 \mathrm{aA}$ & $1.529 \mathrm{aAB}$ & $1.511 \mathrm{aAB}$ & $1.468 \mathrm{bB}$ \\
Fallow area & $1.589 \mathrm{aA}$ & $1.567 \mathrm{aA}$ & $1.550 \mathrm{aA}$ & $1.575 \mathrm{aA}$ \\
\hline
\end{tabular}

Mean followed by similar lowercase letters in the column and uppercase letters in the line are not significantly different at $p$ $\leq 0.05$ by Tukey's test.

Comparing the values of BD in different sampling sites and depths, between the two periods, there were no significant differences in most points (Table XIV).
Total soil porosity (TP) showed the opposite. At six and twelve months after culture implementation, TP was higher in the cultivated area (Table XV). There was no variation of this property along the profile and no significant interaction between sampling sites and depths.

Comparing the means of TP for both evaluations (Table XV), no significant variation between them were found by the paired t-test at 5\% probability.

\section{DISCUSSIONS}

The higher values of MWD were found in the fallow area six months and twelve months (Table III) after culture implementation, which can be justified by the greater amount of large aggregates found there, regarding the managed areas that were mechanically prepared for the culture (row) and cocktails (interrow) implementation. According to Kiehl (1979), absolute 
TABLE XIV

Paired t-test for comparison of the soil bulk density

(BD) between the two periods of collection.

\begin{tabular}{|c|c|c|c|c|c|c|c|c|c|}
\hline \multicolumn{10}{|c|}{ BD } \\
\hline Depth & \multicolumn{2}{|c|}{ Row } & & \multicolumn{2}{|c|}{ Interrow } & \multicolumn{4}{|c|}{ Fallow } \\
\hline & 6 months & 12 months & & 6 months & 12 months & & 6 months & 12 months & \\
\hline$-m-$ & \multicolumn{2}{|c|}{$-m m$} & & \multicolumn{2}{|c|}{$-m m$} & \multicolumn{4}{|c|}{$\longrightarrow m m-$} \\
\hline $0.00-0.10$ & 1.477 & 1.496 & ns & 1.607 & 1.516 & $*$ & 1.589 & 1.591 & ns \\
\hline $0.10-0.20$ & 1.512 & 1.519 & ns & 1.529 & 1.503 & ns & 1.567 & 1.552 & ns \\
\hline $0.20-0.30$ & 1.547 & 1.501 & ns & 1.511 & 1.477 & ns & 1.550 & 1.530 & ns \\
\hline $0.30-0.60$ & 1.479 & 1.478 & $\mathrm{~ns}$ & 1.468 & 1.496 & ns & 1.575 & 1.545 & $*$ \\
\hline
\end{tabular}

*: significant at $\mathrm{p} \leq 0.05$ by paired t-test; ns: non-significant.

TABLE XV

Paired t-test for comparison of the total soil porosity

(TP) between the two periods of collection.

\begin{tabular}{|c|c|c|c|c|c|c|c|c|c|}
\hline \multicolumn{10}{|c|}{ TP } \\
\hline Depth & \multicolumn{2}{|c|}{ Row } & & \multicolumn{2}{|c|}{ Interrow } & \multicolumn{4}{|c|}{ Fallow } \\
\hline & 6 months & 12 months & & 6 months & 12 months & & 6 months & 12 months & \\
\hline$-m-$ & \multicolumn{2}{|c|}{$-m m$} & & \multicolumn{2}{|c|}{$-m m$} & \multicolumn{4}{|c|}{$\longrightarrow \mathrm{mm} \longrightarrow$} \\
\hline $0.00-0.10$ & 0.487 & 0.456 & ns & 0.432 & 0.449 & ns & 0.420 & 0.410 & ns \\
\hline $0.10-0.20$ & 0.460 & 0.452 & $\mathrm{~ns}$ & 0.449 & 0.468 & ns & 0.435 & 0.440 & ns \\
\hline $0.20-0.30$ & 0.453 & 0.464 & $\mathrm{~ns}$ & 0.456 & 0.468 & $*$ & 0.441 & 0.423 & ns \\
\hline $0.30-0.60$ & 0.462 & 0.472 & $\mathrm{~ns}$ & 0.471 & 0.446 & ns & 0.437 & 0.443 & $\mathrm{~ns}$ \\
\hline
\end{tabular}

*: significant at $\mathrm{p} \leq 0.05$ by paired t-test; ns: non-significant.

numbers are not known yet that can provide an interpretation through the results of the aggregates analysis when the soil has good or bad physical properties. Therefore, it is generally accepted that soils with aggregates MWD smaller than $0.50 \mathrm{~mm}$ have low stability. By comparing this value with the MWD obtained in the second evaluation, it was possible to verify that Ultisol showed values higher than $0.5 \mathrm{~mm}$ for both cultivated and fallow areas, which makes the latter be considered relatively resistant to crumbling and dispersion. Silva et al (2006) evaluated the distribution of classes of aggregates obtained by a wet processing of cohesive Ultisol cultivated with sugarcane and observed the decrease of aggregates larger diameter $(>2.00 \mathrm{~mm}$ and $2-1 \mathrm{~mm})$ in the 0.00 to $0.20 \mathrm{~m}$ and 0.20 to $0.40 \mathrm{~m}$ layers.

The GMD showed the highest values for fallow area, although did not differ significantly when only the soil sample depth was considered, and there was no significant interaction between sampling sites and depths (Table IV). Thus, it is possible to conclude that soil aggregation state was similar in all sampling sites after a year of cultivation. Generally, the aggregates mean diameters obtained in the studied areas were less than $1 \mathrm{~mm}$ and, therefore, less than what would be desirable for soil management. The texture of Ultisol may be one of the factors that contribute to the occurrence of smaller diameters. This occurs because, in sandy soils, the aggregation relies mainly on biological processes, due to low clay content. Moreover, the smaller aggregates tend to be more stable and it is more difficult to maintain larger aggregates.

Evaluating aggregates stability by wet processing in sandy-loam soils submitted to organic farming of cotton in comparison with conventionally cultivated areas, Lima et al. (2007) observed that aggregates stability was higher in 
cultivated areas in organic bases, attributing this result to the addition of organic waste and to the reduction of soil plowing. Albuquerque et al. (2005), in turn, found higher aggregates stability in systems that used cover crops when compared to conventional systems, both established in Oxisol, besides positive correlation between the organic carbon of the soil and mean weight diameter of the aggregates.

The results of Tables V and VI show that longer time is needed to improve the physical quality of the soil, probably because the local climatic conditions under irrigation hinders the increase in soil organic matter content, the most important agent of aggregation.

Even though no significant correlation between the organic matter content and soil aggregation indices in the periods evaluated (Table VII), was observed increase to MWD and GMD. This fact may be associated with the effect "priming", which relates to the reduction of $\mathrm{C}$ of the soil right after an input of organic material in the area. Terry et al. (1979) also observed a decrease of the SOC with biosolids application, as well as Hsieh et al. (1981), who reported the occurrence of the effect "priming" in a study about the sewage sludge decomposition under laboratory conditions. Normally, the highest rate of SOM decomposition after the addition of fresh $\mathrm{OM}$ is attributed to the increase of microbial activity, due to the availability of energy substrate. Several authors report the complex relationship between $\mathrm{OM}$ and the use of waste without the expected changes in the increase of the contents along the profile. Most of them do not present clear conclusion on the OM, relating, in some cases, the increase of microbial activity to the low relation $\mathrm{C} / \mathrm{N}$ of the waste. This fact in combination with the nutrients availability, caused the intensification of the microbial activity in this waste and soil, accelerating the rate of $\mathrm{OM}$ decomposition, a mechanism known as "priming effect" (Guedes et al. 2006).
The positive correlation between $\mathrm{Ca}$ and $\mathrm{Mg}$ with MWD (Table VII) means that such elements contributed to the index increase although they did not influence the GMD increase.

Evaluating the aggregate distribution by diameter classes (Table VIII and Table IX), in general, the highest values of weight were found for the class at $0.500-0.250 \mathrm{~mm}$. The fact that similar aggregates weights were found for those sampling sites may explain the failure to obtain significant differences between the values of MWD and GMD for row, interrow and fallow at twelve months.

\section{FLOCCULATION INDEX (FI)}

After six months the FI in the $0.10-0.20$ and $0.20-0.30 \mathrm{~m}$ layers, was the same for the row and fallow area and significantly higher than the interrow (Table XI). The obtainment of low FI for row at $0.10-0.30 \mathrm{~m}$ depth can be related to the organic matter content during this period, which was significantly lower for this area, since the process of flocculation of the clays can also be influenced by organic matter. Twelve months after orchard implementation the inferior values of FI found for the fallow area (Table X) can be connected to the higher values of soil bulk density (Table XIII) found for the area in the same period, considering that lower flocculation index requires more dispersion of clay, which can fill part of the free space.

A reduction in the FI for the sample soil collected on twelve months after cultivation implementation regarding the material collected on six months was observed (Table XII). Such results are not very significant considering the soil aggregation, since higher values were obtained for the index used to evaluate this property (MWD and GMD) at 12 months. Is evident, thus, the less influence to clay in the process of aggregation of this soil, which relies mainly on organic matter due to the small proportion of this particle size fraction in the composition of this soil. 
BulK DENSITY of THE SoIL (BD) AND TOTAL SOIL

POROSITY (TP)

The lowest value of $\mathrm{BD}$ found for the planting row on the layer with $0.00-0.10 \mathrm{~m}$ (Table XIII) can be associated to the preparation of the soil at the time of the system implementation, considering that such preparation breaks structural units, which leads to lower bulk density values. For planting row and fallow area, bulk density values did not differ significantly among depths. In the interrow, major differences occurred among the layers at $0.00-0.10$ and $0.30-0.60 \mathrm{~m}$, the highest and lowest value, respectively.

Unlike what was found at six months, at twelve months there was significant interaction between sites and soil sample depths. In the first evaluation, $\mathrm{BD}$ varied from $1.50 \mathrm{Mg} \mathrm{m}^{-3}$ in the planting row to $1.57 \mathrm{Mg} \mathrm{m}^{-3}$ in the fallow area. Similar values were obtained for a second evaluation: $1.50 \mathrm{Mg} \mathrm{m}^{-3}$ in the row and interrow and $1.55 \mathrm{Mg} \mathrm{m}^{-3}$ in the fallow area.

Cortez et al. (2011) found for sandy/medium Ultisol located in Petrolina-PE under different tillage systems, bulk density values that varied between 1.30 and $1.43 \mathrm{Mg} \mathrm{m}^{-3}$, where considering all evaluated layers. According to the authors these values are not considered critical, since high values of bulk density for sandy surface texture Ultisol have also been found in other studies. Silva et al. (2002) found for sandy loam surface texture Ultisols of Petrolina-PE, bulk density values between 1.46 and $1.50 \mathrm{Mg} \mathrm{m}^{-3}$ in the horizon $\mathrm{A}$, $\mathrm{AB}, \mathrm{E}$, and 1.66 to $2.01 \mathrm{Mg} \mathrm{m}^{-3}$, the subsurface layers, can be considered as an evidence of the presence of hardened layers.

A reduction of bulk density was expected, by increasing the aggregation. However, the aggregation processes were not sufficient to generate such a result in the elapsed time period.

There was no variation of total soil porosity (TP) along the profile and no significant interaction between sampling sites and different depths (Table XV). Cortez et al. (2011) found for Ultisol with sandy-medium texture located in Petrolina-PE, TP values of $0.45,0.46$ and $0.43 \mathrm{~m}^{3} \mathrm{~m}^{-3}$ in $0.00-0.10$, $0.10-0.20$ and $0.20-0.30 \mathrm{~m}$ layers, respectively, in the area submitted to different tillage implements. For the soil without preparation, the TP ranged from $0.48 \mathrm{~m}^{3} \mathrm{~m}^{-3}$ between 0.00 and $0.10 \mathrm{~m}$ at 0.42 $\mathrm{m}^{3} \mathrm{~m}^{-3}$ between 0.20 and $0.30 \mathrm{~m}$. Silva et al. (2002) found for Ultisol also located in Petrolina-PE TP values ranging between 0.44 and $0.37 \mathrm{~m}^{3} \mathrm{~m}^{-3}$ to $0.60 \mathrm{~m}$ depth in the profile.

\section{CONCLUSIONS}

The organic farming of wine grapes contributed to the process of soil aggregation;

The bulk density and total soil porosity did not differ significantly between the evaluations, but were within the critical limits for sandy soils;

The index flocculation did not have a great influence on the aggregates formation, being this process influenced by organic matter.

The period of one year was considered short to obtain conclusive results in improving the soil quality by organic farming, since there are difficulties in tropical soils in promoting significant increases in organic matter content in short time.

\section{ACKNOWLEDGMENTS}

We would like to extend our gratitude to Conselho Nacional de Desenvolvimento Científico e Tecnológico (CNPq) and Fundação de Amparo à Ciência e Tecnologia de Pernambuco (FACEPE) for the financial support and fellowships, and to Winery Bianchetti Tedesco, in Petrolina, Brazil, for the opportunity carry out field experiment in a commercial wine grape orchard.

\section{RESUMO}

O objetivo desse trabalho foi avaliar os efeitos do cultivo orgânico de videira de vinho sobre características físicas e químicas de Argissolo da região semiárida do Brasil. Foram coletadas amostras de solo na linha e entrelinha de plantio e em área de pousio nas profundidades de 0,00-0,10, 0,10- 
0,20, 0,20-0,30 e 0,30-0,60 m. As amostras foram coletadas aos seis e doze meses após a implantação da cultura para avaliação do estado de agregação, densidade do solo, porosidade total, índice de floculação, matéria orgânica, cálcio, magnésio e sódio. Os resultados foram submetido à análise estatística. A adoção do cultivo orgânico contribuiu para o processo de agregação do solo. A densidade do solo e a porosidade total não diferiram significativamente entre as avaliações, entretanto, encontraram-se entre os limites críticos para solos arenosos agricultáveis. A floculação das argilas, não colaborou na formação de agregados, sendo este processo influenciado principalmente pela matéria orgânica. O período de um ano foi considerado curto para obtenção de resultados conclusivos sobre a melhoria da qualidade do solo sob cultivo orgânico, tendo em vista a dificuldade de incremento de matéria orgânica em solos de regiões tropicais.

Palavras-chave: estabilidade de agregados, cultivo orgânico, qualidade do solo, vitivinicultura.

\section{REFERENCES}

Albuquerque JA, Argenton J, BAYER C, Wildner LP AND KUNTZE AG. 2005. Relação de atributos do solo com a agregação de um Latossolo Vermelho sob sistemas de preparo e plantas de verão para cobertura do solo. R Bras Ci Solo 29: 415-424.

BolONHEZ GL. 2009. Vinho e ecologia: a moda verde dos vinhos. R Adega 41: 1-4.

CAlado V And Montgomery DC. 2003. Planejamento de experimentos usando Statistica. Rio de Janeiro: E-Papers Serviços Editoriais, 260 p.

Castro Filho C, Muzilli O AND Podanoschi AL. 1998. Estabilidade dos agregados e sua relação com o teor de carbono orgânico num Latossolo Roxo distroférrico, em função de sistemas de plantio, rotações de culturas e métodos de preparo das amostras. R Bras Ci Solo 22: 527-538.

CORTEZ JW, Alves ADS, MOURA MRD, OLSZEVSKI N AND NAGAHAMA HJ. 2011. Atributos físicos de Argissolo Amarelo do semiárido nordestino sob sistemas de preparo. R Bras Ci Solo 37: 1207-1216.

CRASWELl ET AND LEFROY RDB. 2001. The role and function of organic matter in tropical soils. Nutrient Cycling and Agroecosystem 61: 7-18.

DORAN JW. 2002. Soil health and global sustainability: translating science into practice. Agriculture, Ecosystems and Environment: 88: 119-127.

EMBRAPA - EMPRESA BRASILEIRA DE PESQUISA AGROPECUÁRIA. 1997. Manual de métodos de análise do solo. Rio de Janeiro: Centro Nacional de Pesquisas de Solos, 212 p.
Guedes MC, Andrade CA, Poggiani F and Mattiazzo ME. 2006. Propriedades Químicas do Solo e Nutrição do Eucalipto em Função da Aplicação de Lodo de Esgoto. R Bras Ci Solo: 267-280.

HSIEH YP, Lowell AD AND MotTo HM. 1981. Modeling sewage sludge decomposition in soil: I. Organic carbon transformation. J Environ Qual 10: 54-64.

KIEHL EJ. 1979. Manual de edafologia: relações solo-planta. São Paulo: Agronômica Ceres, 262 p.

LARSON WE AND PIERCE FJ. 1994. The dynamics of soil quality as a measure of sustainable management. In DORAN, J. W. ET AL. (Eds), Defining soil quality for a sustainable environment, Madison: Soil Science Society of America, p.37-51. (SSSA special publication, 35).

LIER QJV AND ALBUQUERQUE JA. 1997. Novo método para calcular o diâmetro médio de agregados de solos. R Bras Ci Solo 21: 699-705.

Lima CGR, CARVAlho MP, Mello MM AND Lima RC. 2007. Correlação linear e espacial entre a produtividade de forragem, a porosidade total e a densidade do dolo de Pereira Barreto (SP). R Bras C Solo 31: 1233-1244.

Melo VF, Moura R, Toledo FH, Lima VC And GHidin AA. 2008. Morfologia de agregados de Latossolos Bruno e Vermelho do estado do Paraná, avaliada por imagens obtidas em scanner. R Bras Ci Solo 32: 85-99.

OQUIST KA, STROCK JS AND MULLA DJ. 2007. Influence of alternative and conventional farming practices on subsurface drainage and water quality. Journal of Environmental Quality 36: 1194-1204.

Protas JFS, Camargo UA and Melo LMR. 2008. A vitivinicultura brasileira: realidade e perspectivas. Artigos técnicos. Embrapa Uva e Vinho. Disponível em: < www. cnpuv.embrapa.br/publica/artigos/vitivinicultura/>. Acesso em 17 out. 2011.

RoBERT M. 2001. Soil carbon sequestration for improved land management. Rome: FAO, 58 p. (World Soil Resources Reports, 96).

RuIz HA. 2004. Métodos de análises físicas do solo. Universidade Federal de Viçosa - Departamento de Solos, 22 p.

Silva AJN, CABEDA MSV, CARVAlho FG. 2006. Matéria orgânica e propriedades físicas de um Argissolo Amarelo Coeso sob sistemas de manejo com cana-de-açúcar. R Bras Eng Agríc Ambiental 10: 579-585.

SiLVA FAS AND AzEVEdo CAV. 2002. Versão do Programa computacional Assistat para o sistema operacional Windows. R Bras Prod Agroindustriais 4: 71-78.

Silva MSL, Klamt E, CAVAlCANTI AC AND KROTH PL. 2002. Adensamento subsuperficial em solos do semiárido: processos geológicos e/ou pedogenéticos. R Bras Eng Agríc Ambiental 6: 314-320.

TERry RE, NeLson DW AND SOMmers LE. 1979. Carbon cycling during sewage sludge decomposition in soils. Soil Sci Soc Am J 43: 494-499.

VITAL T. 2009. Vitivinicultura no Nordeste do Brasil: Situação recente e perspectivas. R Econ Nordeste 40: 499-524. 
